\title{
Problems of modernization and technical re-equipment of Russian machine-building enterprises
}

\author{
Olga Antonyan ${ }^{1}$, Elena Karpushko ${ }^{1,}$, and Anna Solovyeva ${ }^{1, *}$ \\ ${ }^{1}$ Volgograd State Technical University, Institute of Architecture and Construction, 400074 Volgograd. ul. Akademicheskaya, 1, Russia
}

\begin{abstract}
Article substantiates the need for modernization and technical re-equipment in Russian Federation. The goal of the research and tasks for achieving this goal has been determined. The existing conditions for development of machine building complex of Russian Federation in recent history and dynamics of economic indicators that characterize it in recent years are considered. Trends in domestic machine building industry are revealed, which directly characterize the slowdown in the rate of country's economic functioning. Urgency of modernization and technical re-equipment of machine-building, its upgrading on the basis of wide introduction of the latest scientific and technical achievements and advanced technologies, is underlined, as without advancing development of machine building, it is impossible to solve problems of technological safety and problems relating to social sphere and standard of living of country's population. Particular attention is paid to the main problems and tasks of modernization, technical reequipment of engineering enterprises. It is noted that at present stage the demand for modernization of Russian engineering is obvious. The results of the research show how urgent it is to change the forms and methods of production organization, re-equipment of technological capacities, and introduction of modern management systems. However, in order to correctly formulate the main priorities and directions of modernization, an in-depth analysis is needed.
\end{abstract}

\section{Introduction}

Nowadays, industry modernization, its technical reequipment is based on the widespread introduction of the latest scientific and technological achievements and advanced technologies which are a top priority for Russian economy. One of the most important tasks is accelerated development of machine building, an industry that provides not only modernization of entire national economy, but also contributes to the increase in qualification level of population [4].

Today, fundamental modernization of production and use of modern technologies, materials and equipment is a necessary condition for increasing the competitiveness of products and efficiency of work of most domestic enterprises. Therefore, the subject of the study, devoted to the problems of modernization and technical reequipment of Russian machine-building enterprises is relevant today.

The purpose of the study is to examine the problems of modernization and technical re-equipment of Russian engineering enterprises and to search for strategic directions for their development. To achieve this goal, it is necessary to:

- give an analysis of the results of machine-building complex development of Russian Federation;

- define the main tasks of modernization and technical re-equipment of machine-building enterprises;
- develop directions for improving the processes of modernization and technical re-equipment at the enterprises of the machine-building industry in Russia.

During the problem's studying process, works of Russian and foreign scientists, and own developments in this direction were used.

\section{Results of development of machine- building complex in Russia}

\subsection{Conditions for development of machine building complex in recent history of Russia}

Development of machine building in Russia during 1990-2016 is indicative and reflects all country events related to privatization, economy decline of 1990 s, series of financial crises and increase in production in early 2000s. All this led to the loss of competitive positions in the world market and growth of imports under category of «machinery, equipment and vehicles» [2]. Nowadays, enterprises of this industry are under considerable pressure from outside, connected with economic sanctions from European Union and United States. Also, depreciation of the national currency imposes additional restrictions on the development of the considered sector. Existing conditions from one country can be regarded as threats to the existence of machine-building in our country; on the other hand, there are additional

\footnotetext{
Corresponding author: solovan@yandex.ru
} 
opportunities and competitive advantages in comparison with Western producers.

\subsection{Indicators of machine-building complex development for 2016}

The year of 2016 was difficult for the entire Russian machine-building industry. Shipbuilding industry has shown the need to activate fundamental and exploratory research to create promising marine equipment for various purposes. For development of shipbuilding industry, the federal targeted and state programs are being implemented in the country, such as «Development of shipbuilding and engineering for development of offshore fields for 2013-2030» and «Development of defense industry complex of Russian Federation for 2016-2025».

The year 2016 was not easy for motor-car industry. The production of passenger cars in 2016 decreased by $27.7 \%$, which was mainly due to a decrease in personal income and investment activity, as well as a reduction in consumer lending and leasing operations due to higher interest rates on loans. Volume of domestic car market for the specified period also decreased by $35.7 \%$. The production of trucks in 2016 decreased by $14 \%$, which is also related to the relative saturation of this market and a reduction in the freight turnover of road transport [12].

At the end of 2016, there was also a decline in the agricultural machinery industry, which amounted to $14.3 \%$.

In general, in 2016, the dynamics of production in the machine building complex of Russia deteriorated. The total production in the machine-building industries decreased by $10.3 \%$ as compared to the same period. The current decline in production in engineering in 2016 was predicted, as this industry was the most sensitive to instability in the investment climate.

\section{Modernization and technical re-equipment of engineering enterprises as a decisive factor for increasing competitiveness}

\subsection{Prerequisites for modernization and technical re-equipment of machine-building industry}

The implementation of state programs to accelerate the pace of economic development of the country is possible only if the system of modernization of domestic machine-building complex is accelerated, which determines the main factors for development of productive forces in the medium and long term. As numerous researches of scientists show, without advancing development of machine building it is impossible to solve problems of technological safety and problems related to the social sphere and standard of living of the population. In recent years, negative trends in domestic engineering have become noticeable, which directly characterize the slowdown in the pace of country's economy functioning. It is necessary to note first of all:

1. Decrease in output volume of science-intensive products, creation of which is associated with the use of scientific and technological progress.

2. Slow formation and development of innovative potential due to low level of innovative activity.

3. Reducing competitiveness of machine-building enterprises.

4. Significant long-term aging of all elements of fixed capital (and, above all, active part of the basic production assets of machine-building enterprises).

5. Incompleteness of the implementation of conversion programs for many large enterprises in the country.

6. Slowing down the pace of lower costs for the production of industrial products in engineering.

7. Weakening of functional-technological and economic ties in the system of «metallurgy and machine building».

8. Investment failure to carry out works related to the fundamental modernization of the material and technical base of engineering enterprises.

9. Insufficiently effective application of «double» technologies in machine building, which allows to increase (according to the data of domestic and foreign machine-building enterprises) the effectiveness of production operations without significant investment.

10. Aging of labor in many machine-building centers of the country.

11. Complexity of solving the organizational and economic problems arising in connection with the need to carry out activities related to import substitution in the leading sub-branches of machine building in Russia.

In modern conditions, a special role is assigned to solving the problems of increasing efficiency of machine building - locomotive for development of the entire industrial complex of the country. Over the past 15 years, the pace of development of this complex has significantly decreased due to a number of reasons, and primarily because of the underestimation of the significance of the implementation of the new wave of industrialization in the leading sectors of the country's economy. Studies show that the development of industry in any country is determined by the production potential of machine building and metalworking.

\subsection{The main problems and tasks of modernization and technical re-equipment of engineering enterprises}

Nowadays, modernization and technical re-equipment of machine building, its improvement on the basis of widespread introduction of the latest scientific and technical achievements and advanced technologies is an urgent need. One of the most important tasks is the acceleration of the development of machine building, an industry that provides not only modernization of the entire national economy, but also contributes to the increase in the qualification level of the population [4].

It should be noted that Russia's machine building industry is distinguished by a very high degree of production concentration. Prospects for modernization of 
enterprises directly related to the development of its product markets, stability and efficiency of economic ties with major consumers [17].

However, it must be understood that access to financial resources is by no means the only condition for the implementation of modernization projects. Thus, in some large machine-building enterprises it is possible to observe how financial and other results of large-scale investment projects do not correspond to the declared ones, time for transition to new technologies is delayed by several years [1].

In addition, at each stage of the investment project of modernization and technical re-equipment, various organizational and managerial problems arise related to the lack of automation and standardization of processes, lack of skills for working with standard software for some responsible executors, need for clarifications and adjustments, lengthy process of providing services of necessary information and coordination of documentation in connection with a large number of matching persons, etc.

As a result, almost half of the time from the whole process of delivery and putting into operation occupies work with documentation, besides the most part from this half takes time, required for document's accommodation.

One of the reasons for this state of affairs is linearfunctional structure of enterprise management, which stimulates functional isolation and reduces effectiveness of interactions between individual participants in end-toend processes. All this leads to non-compliance with the timing of the implementation of modernization measures and availability of undeveloped and rolling investments from year to year, which in turn requires additional time and labor to update target specifications and other necessary documentation.

Modernization in the framework of engineering business groups is carried out through the following activities:

- purchase of Russian-made equipment;

- purchase of second-hand imported equipment;

- purchase of new imported equipment, technical level of which corresponds to the world one.

Modernization through the acquisition of Russian equipment has its positive and negative sides. On the one hand, domestic equipment is easy to operate and cheap. Its use stimulates the development of machine and machine building industries, thereby gradually reducing the dependence of domestic industry from import. On the other hand, the acquisition of Russian equipment, technical level of which is lower than the world level, creates the prerequisites for a future technological backwardness of enterprises.

The acquisition of used imported assets is widespread among Russian machine-building enterprises due to their lower cost compared to new equipment, on the one hand, and relatively high reliability, on the other hand. Usually, their wear and tear is low, as in developed countries the intervals between replacement of assets for new, constantly improving models are constantly reduced.
Negative side of modernization through the use of foreign equipment is increase of dependence of engineering enterprises on imports.

Usually Russian companies implement several types of measures to update fixed capital in parallel. Thus, certain advanced imported equipment units are purchased for operations that critically affect quality and cost of production.

Less advanced assets are acquired to perform most of the operations of main and auxiliary production. Usually such assets are built into technological chains, mainly consisting of domestic elements.

As for the quantitative aspect of investments, mainly projects with relatively low reported costs and short payback periods are being implemented. Such projects, as a rule, are aimed at maintaining a stable volume of production or at a slight increase in production, reduction in the cost of production, as well as implementation of activities prescribed by safety regulations, social and environmental regulations.

Projects with high adjusted costs and long payback periods for creation of new and radical changes in existing production complexes (full-scale modernization of production) are rare.

While development of modernization measures, in particular when developing the concept of a new production (or reconstruction of an existing one), a new technology or its partial improvement, along with the solution of technical and technological tasks, optimization of movement and stocks in the supply of production, minimization of the duration of the production cycle, minimization of losses and downtime, modernization of the entire technological chain of the production cycle.

The general tasks of modernizing the production of innovative industrial enterprises can be structured into several main groups:

- technical modernization (renewal of fixed capital due to its physical or moral depreciation);

- technological modernization (introduction of innovative technologies on the basis of own developments or using various forms of technology transfer);

- product modernization (expansion of the range of previously manufactured products through their modification or cardinal technological upgrade, development of innovative products);

- modernization of the management system (improvement of the enterprise management system. For example, projects to introduce new information technologies, to remove inefficient capacities and noncore productions for outsourcing, translation of the reporting system to international standards, etc.);

- modernization of the personnel management system of the enterprise (changes in the structure of the personnel and its qualitative level due to the transformation of the hiring-selection system, carrying out programs of inservice training and retraining of personnel). 


\subsection{Potential directions for modernization and technical re-equipment improvement of engineering enterprises}

At this stage, the need for Russian engineering in the modernization is obvious. The results of the research show how urgent it is to change the forms and methods of organizing production, re-equipping technological capacities, introducing more modern management systems. However, in order to properly formulate the main priorities and directions of modernization, an indepth analysis is needed.

According to the observations of Russian researchers, large enterprises often implement large-scale investment projects, practical significance and financial results of which differ significantly from the stated goals, the result of technical re-equipment is ineffective equipment, capabilities of which are far from being used completely, and the transition to new technologies is delayed by several years.

Analysis of the expediency of modernization of the machine-building enterprise is represented in the form of a comprehensive, step-by-step and element-wise research, purpose of which is:

- determining the level of sufficiency of capacity development for carrying out modernization activities;

- identification of possible barriers / obstacles in the course of modernization and development of measures to eliminate them;

- definition of priority areas for modernization.

Modernization projects, as a rule, are implemented with the aim of increasing production volumes and reducing the cost of production (through the use of advanced technologies and materials, optimizing the number of production personnel, saving energy resources, freeing production spaces, etc.), developing new products and improving the quality of already existing [18]. The values of potential effects for machine-building enterprises with an obsolete equipment park are presented in Table. 1.

Table 1. Potential effects of modernization

\begin{tabular}{|c|c|c|}
\hline Main effects & $\begin{array}{c}\text { During } \\
\text { updating of } \\
\text { equipment } \\
\text { park }\end{array}$ & $\begin{array}{l}\text { During using of old } \\
\text { equipment park with } \\
\text { improvement of } \\
\text { technology and use of } \\
\text { modern tools and } \\
\text { equipment } \\
\end{array}$ \\
\hline $\begin{array}{c}\text { Reduction of } \\
\text { electricity } \\
\text { costs }\end{array}$ & \multirow{3}{*}{ in 3-4 times } & \multirow{3}{*}{ in $1,2-1,5$ times } \\
\hline $\begin{array}{l}\text { Reduction of } \\
\text { production } \\
\text { space }\end{array}$ & & \\
\hline $\begin{array}{c}\text { Reduction of } \\
\text { production } \\
\text { personnel }\end{array}$ & & \\
\hline $\begin{array}{c}\text { Cost } \\
\text { Reduction }\end{array}$ & $\begin{array}{l}\text { up to } 50 \% \\
\text { (taking into } \\
\text { account the } \\
\text { cost of new } \\
\text { equipment) }\end{array}$ & up to $20 \%$ \\
\hline
\end{tabular}

Consideration of modernization problems and technical re-equipment at the machine-building enterprises allows suggesting the main directions for its improvement:

1) provision of the company's units with personnel in accordance with the calculation of the number and required qualifications;

2) implementation of a training program using the capabilities of a corporate training center, cooperation with educational institutions of cities;

3) preservation and development of intellectual, scientific and technical potential of the enterprise;

4) creation of motivation system, development and professional growth of employees, aimed at maximum professional and personal self-realization of employees; 5) improving corporate culture and increasing social attractiveness of the enterprise.

\section{Conclusion}

Thus, the main task of industrial policy at the present stage is technological modernization of production and increasing competitiveness of products of machinebuilding enterprises. One of the most important factors ensuring the solution of this problem is qualitative and quantitative composition of used means of production.

Future will be determined by whether the industries will develop on the basis of the achievements of Russian science and technology, or it will be limited only to the transfer of foreign productions to Russia, as a territory with a relatively cheap labor force and with «not the first freshness» technologies.

Modernization of Russian machine building industry no longer needs to be delayed. Today, the radical modernization of production facilities and the use of modern technologies, materials and equipment are a prerequisite for increasing the competitiveness of products and the efficiency of the work of most domestic enterprises.

\section{References}

1. O.N. Antonyan, E.N. Karpushko, A.S. Solovyeva, 16th International Scientific Conference Globalization and Its Socio-Economic Constructions 1, 50-58 (2016)

2. N. I. Aksenova; E. A. Prikhodko, BK 2: Political sciences, law, finance, economics and tourism conference proceedings III, 483-490, (2016)

3. C. Azani, R. Khorramshahgol, 9th World MultiConference on Systemics, Cybernetics and Informatics 1, 298-303 (2005)

4. S.P Baranenko, K.D. Busygin, Actual problems of the humanities and natural sciences 9, 94-102 (2014).

5. J. Bakowski, Sustainable building and refurbishment for next generations, 35-38 (2013) 
6. L. Boronina, D. Ronzhina, 7th international conference of education, research and innovation, 5921-5928 (2014)

7. A. Costea, N Rachieru, R. Nita, 13th international conference modern technologies, quality and innovation, 203-206 (2009)

8. Z.V. Danilovich, Z.V. Viktorovich, B.V. Vasilievich, Asian Social Science 10(24), 28-34 (2014)

9. L.D. Gitelman, M.V Kozhevnikov, Economy of Region 13(1), 204-215 (2017)

10. N.V. Kalenskaya, O.V. Pratchenko, Asian Social Science 11(11), 357-363 (2015)

11. N Kalenskaya, First global conference on contemporary issues in education, 203-208 (2015)

12. V.V. Kobzev, M.K. Izmailov, Organizer of production 25(1), 69-83 (2017).

13. E.A. Kolesnik, III international scientific symposium on lifelong wellbeing in the world $\mathbf{1 9}$, 336-343 (2017)

14. Z. Mingaleva, H. Danilina, Life Science Journal 11(8), 211-215 (2014)

15. M.L. Melnikov, L.A. Gracheva, Gornyi Zhurnal 6, 65-67 (2014)

16. B. Melnikas, 7th international scientific conference business and management, 416-425 (2012)

17. I.I. Novakivskyi, N.S. Lushchak, V.Z. Borbulevych, Marketing and management of innovations 3, 30245 (2016)

18. Yu.K. Salnikova, Vestnik of the South-Russian State Technical University 5, 54-59 (2016).

19. A. Schoenmann, J. Greitemann, G. Reinhart, Sixth international conference on changeable, agile, reconfigurable and virtual production 52, 198-203 (2016)

20. Y. Vertakova, Y. Polozhentseva, M. Klevtsova, Innovation management, development sustainability, and competitive economic growth I VII, 2168-2178 (2016) 